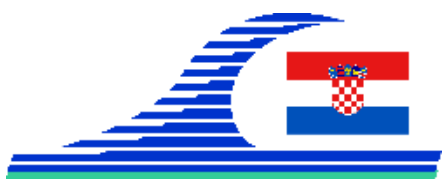

\title{
Coastal port planning as a touristic development
}

\author{
Heiner HAASS 1
}

1. Anhalt University, Bernburg, Germany.

Zentrale@d-Marina-consult.de

\begin{abstract}
:
Nautical tourism is the most economic branche. The diversify of this branche in the next years are for cruise and ferry shipping and superyachting. The indirectly sector of this are huge and the relationship between ports and towns are very innovative. Regional networks of ports are necessary. The economic view shows direct and indirect effects which are important for the development of next years.
\end{abstract}

\section{Keywords:}

Nautical tourism, Ports, Settlement, White industry, Cruise shipping, Superyachts, Port development by History, Economic benefits, Direct and indirect effects, Ecological and social sustainability.

\section{Development}

Mediterranean towns and ports own a lot of potential for positive economic development. In the past, this development contains various goals, e.g. political, strategic, settlement, fishery industry and others. Actually, the touristic development is the most important and the most economic one. The most economic effects around the Mediterranean Sea are generated by the touristic industry, the so called 'White Industry'. At the Mediterranean area, the nautical tourism is the most important part of the touristic business. For many communities, boating and yachting are the biggest factor. In the next few years, the nautical tourism will increase and diversify itself. Boating and yachting are the well - known examples. Likewise are cruise shipping, ferry shipping and super - yachting.

From the economic point of view, the maritime departments like wharfs, repair- shops, schools and consulting are the most important ones. The maritime industry will increase and grow. For the future of the Mediterranean port communities, this gets more and more important. It is the goal of the maritime industry to identify this development and be geared to it. So it is important to integrate the former and historical development of the ports and communities. The story of the port and the community also has to be integrated. Working this way, a lot of changes and themes are offered for the port development. Each port is individual and different, so there are a lot of different ports and there is a chance to make specific developments. 
Mediterranean rocky coasts:

Features, processes, evolution and problems

A regional network can be made by combining different cities and their ports via nautical tourism ports. The biggest success in business and economic is guaranteed when the development is made in this way.

The working effects of the nautical tourism are very interesting. One the one hand there are direct effects, on the other hand there are indirect effects.

The direct effects are coming from marinas, wharfs or charters. They are limited and are also depending on the seasonal touristic situations and the economic. The side effects are much bigger and also more interesting when it comes to economic. The range is defined through hotels, gastronomy, shops, traffic, repairing and installing and more. Other indirect maritime offers are touristic offers like museum, churches, parks etc. Also the acknowledgement of local and regional inhabitants is important. When this attractive nautical infrastructure is made, it is not just made for tourists; it is made for the inhabitants too. This makes the planning more attractive than just the touristic part.

\section{References}

HAASS H. (2005). Stadt am Wasser: Neue Chancen für Kommunen und Tourismus. Frankfurt: Ed. Frankfurter Societäts-Druckerei. 128 p. ISBN: 978-3-7973-0898-6

HAASS H. (2010). StadtWasser:Wasserkonzepte für die Stadtgestaltung. Stuttgart: Ed. Fraunhofer-IRB-Verlag. 221p. ISBN: 978-3-8167-8108-0

HAASS H. (2017). Grundwissen Tourismus Architektur. München. Ed.UTB Lucius, 132p. ISBN 978-3-8252-4738-6 